\title{
Secondary pupillary membranes treated by the pars plana/pars plicata approach: long-term results of 108 cases
}

\author{
CLAUDIO P. JUAREZ, GHOLAM A. PEYMAN, MOTILAL RAICHAND, AND \\ MORTON F. GOLDBERG
}

From the Department of Ophthalmology, University of Illinois Hospital Eye and Ear Infirmary, Chicago, USA

SUMMARY One hundred and eight pupillary membranes treated with the vitrophage through a pars plicata or pars plana approach were evaluated for long-term results. The average follow-up was 3.86 years, with a range of 1 to 7 years. No major operative complications were encountered. Anatomical success was achieved in all cases. Vision improved in $67.5 \%$ of eyes. In 4 cases $(3.7 \%)$ postoperative visual acuity was worse, because of glaucoma secondary to previous blunt ocular trauma. Six cases showed delayed rhegmatogenous retinal detachment postoperatively. These could not be attributed to the surgical procedure per se.

In spite of several years of continued refinement of pupillary membrane surgery by means of an anterior limbal approach ${ }^{1-13}$ the complications of vitreous loss, vitreous incarceration in the wound, flat anterior chamber, or complications arising from wound healing have been only partially minimised. After the pars plana approach was conceived in the early 1970s the possibility of treating anterior segment diseases by similar methods became apparent. ${ }^{14-17}$ The removal of pupillary membranes via the pars plana approach offers the advantage of creating a large pupillary opening and of removing the anterior vitreous, thus minimising the above-mentioned complications and also eliminating the scaffold for repeated opacifications.

The present study discusses the long-term results of 108 consecutive pupillary membranes treated by the pars plana/plicata approach. Average follow-up time was 3.8 years, with a range of 1 to 7 years (Fig. 1).

\section{Materials and methods}

PATIENT SELECTION

All patients with secondary membranes who underwent a pars plana or pars plicata procedure at the Illinois Eye and Ear Infirmary between January 1972

Correspondence to Professor Gholam A. Peyman. University of Illinois Hospital Eye and Ear Infirmary, 1855 W Taylor Street, Chicago. IL 60612, USA and July 1979 were reviewed. The wide-angle vitrophage was used in the majority of the cases.

Pupillary membranes were classified as traumatic (perforating and nonperforating), inflammatory, and those that developed after operations for congenital cataract. The membranes in all cases developed after previous cataract surgery. Occluded, partially occluded, and updrawn pupils commonly resulted from contraction of residual lens material, prolifera-

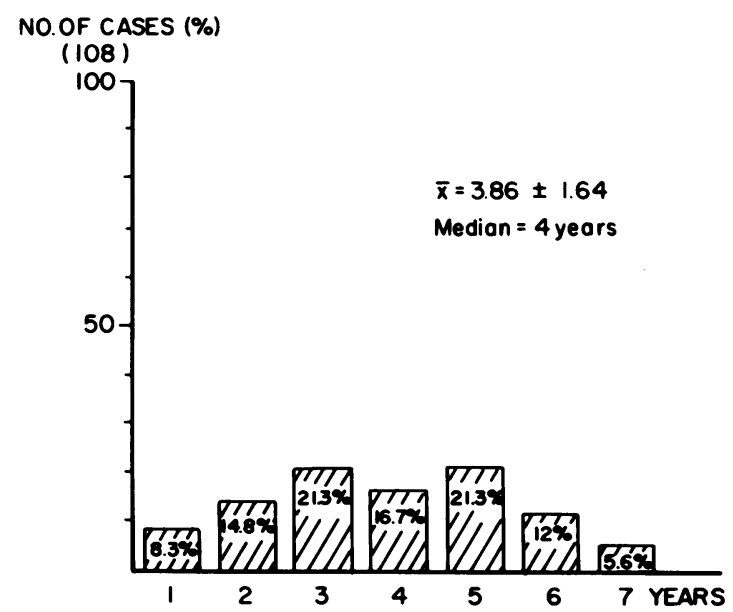

Fig. 1 Follow-up duration of patients with pupillary membranes. Note median follow-up duration of 4 years. 


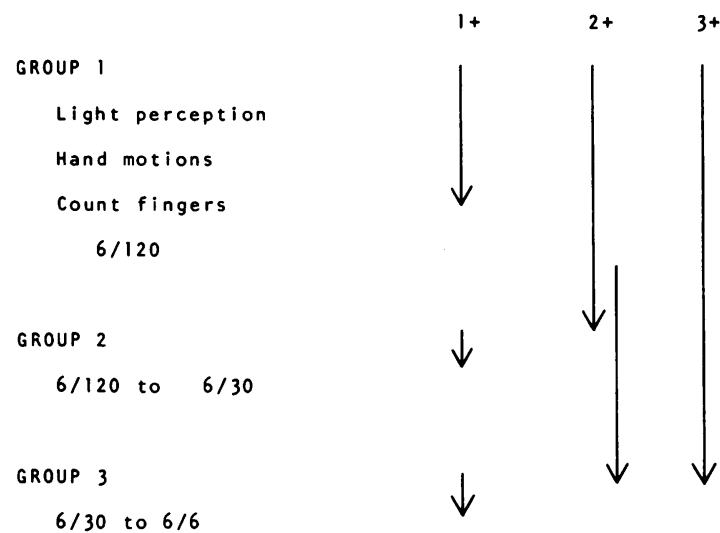

Fig. 2 Peyman-Sanders classification of visual improvement following vitrectomy.

tion of iris pigment epithelium over vitreolenticular remnants, or contraction of vitreous extending to the previous cataract wound.

In all cases simple discissions were judged to be inappropriate because of the thickness of the membranes, amount of debris, or previous surgical failure. No patients who had undergone previous pars plana or pars plicata procedures were included. Those who had had operations for disease of the posterior segment of the eye, such as retinal detachment operations, were also excluded from the study. Cases in which the vitrophage was inserted through a limbal incision were also excluded.

PREOPERATIVE EVALUATION

All patients underwent a complete preoperative eye examination with special emphasis on retinal function. Ultrasound was done when indicated to evaluate the status of the posterior segment of the eye.

\section{ANAESTHESIA}

The majority of surgical procedures ( 84 of 108 cases; $78 \%$ ) were performed with the patient under local anaesthesia. Exceptions were children, anxious adults, and mentally retarded patients.

\section{SURGICAL TECHNIQUE}

After a standard preparation for the operation traction sutures were passed through both eyelids, followed by 4-0 black silk traction sutures under the insertions of the 4 rectus muscles. After adequate exposure was obtained a limbal peritomy was made, usually in the inferotemporal quadrant. In children under 3 years old a 3.5 to $4 \mathrm{~mm}$ long sclerotomy was made with a no. 15 Bard Parker or a no. 64 Beaver blade $2.5 \mathrm{~mm}$ posterior and parallel to the limbus (pars plicata approach). In older children and in adults the sclerotomy was similar in length but was located 3 to $4 \mathrm{~mm}$ from the limbus (pars plana approach). The underlying ciliary body was cauterised or diathermised gently. A mattress suture of 5-0 polyglactin (Vicryl) or 4-0 polyfilament (Supramid) was passed through the lips of the sclerotomy, and a double throw knot was applied loosely. The suture material was then looped out of the sclerotomy. A no. 52S Beaver blade was inserted through the sclerotomy, initially perpendicular to the globe through the midvitreous cavity, and then the knife was angulated anteriorly to engage and slit the membrane. The knife was withdrawn and replaced with the vitrophage. In some cases the initial insertion was made with a Ziegler knife to discise the membrane several times. In this manner several narrow triangles of tissue were made more accessible for aspiration with the vitrophage. Once the vitrophage was inserted, the preplaced mattress suture was drawn up snugly.

The vitrophage removed the membrane, approximately $80 \%$ of the vitreous, and, when possible, any anterior synechiae or other iris adhesions. The cutting port of the vitrophage was always rotated anteriorly (toward the cornea) while the membrane was initially cut. The membrane was aspirated first into the cutting port, then a hole was cut and enlarged. Any haemorrhage that occurred during cutting usually stopped spontaneously when the intraocular pressure was increased. If bleeding continued, the vessels were coagulated with diathermy.

\section{Results}

Most of the surgical operations were done by one of us (G.A.P.); the remainder were done either by staff members or by residents under direct supervision. We used the Peyman-Sanders classification for criteria of visual improvement following vitrectomy ${ }^{18}$ (Fig. 2). All visual acuities represent the latest visit to the institution by the patient. Anatomical success was defined as the creation of a clear pupillary space and clear media with a $6 / 6$ view of fundus details. Because of patient's age or mental retardation some visual acuities could not be measured. Unimproved visual acuity was either a result of amblyopia or of associated diseases in the posterior pole not identified before surgery. Such diseases included optic atrophy secondary to direct trauma to the optic nerve and/or optic atrophy secondary to end stage glaucoma, macular scars, myopic degeneration (Fuchs's spot with subretinal neovascularisation), and chorioretinitis sclopetaria. ${ }^{19}$

In our 108 cases of secondary pupillary membranes 
Table 1 Long-term results in patients with pupillary membranes removed via pars plana or plicata

\begin{tabular}{|c|c|c|c|c|c|c|c|c|}
\hline \multirow[t]{2}{*}{ Diagnosis } & \multirow{2}{*}{$\begin{array}{l}\text { No. } \\
\text { of } \\
\text { eyes }\end{array}$} & \multicolumn{3}{|c|}{ Visual improvement } & \multirow{2}{*}{$\begin{array}{l}\text { Other } \\
\text { visual } \\
\text { status* }\end{array}$} & \multirow{2}{*}{$\begin{array}{l}\text { Vision } \\
\text { unchanged }\end{array}$} & \multirow{2}{*}{$\begin{array}{l}\text { Vision } \\
\text { worse }\end{array}$} & \multirow{2}{*}{$\begin{array}{l}\text { Anatomical } \\
\text { success }\end{array}$} \\
\hline & & $3+$ & $2+$ & $1+$ & & & & \\
\hline $\begin{array}{l}\text { Membranes due to previous trauma with } \\
\text { perforating corneal injury } \\
\text { Membranes from previous blunt trauma } \\
\text { Inflammatory membranes } \\
\text { Development of membranes after } \\
\text { congenital cataract procedures }\end{array}$ & $\begin{array}{r}39 \\
45 \\
5 \\
19 \\
108\end{array}$ & $\begin{array}{c}4 \\
43 \\
(39 \cdot 8)\end{array}$ & $\begin{array}{c}11 \\
5 \\
1 \\
1 \\
18 \\
(16 \cdot 6)\end{array}$ & $\begin{array}{c}3 \\
8 \\
1 \\
\\
12 \\
(11 \cdot 1)\end{array}$ & $\begin{array}{c}6 \\
3 \\
1 \\
14 \\
24 \\
(22 \cdot 2)\end{array}$ & $\begin{array}{c}7 \\
(6 \cdot 4)\end{array}$ & $\begin{array}{l}4 \\
(3 \cdot 7)\end{array}$ & $\begin{array}{r}39 \\
45 \\
5 \\
\\
19 \\
108 \\
(100)\end{array}$ \\
\hline
\end{tabular}

*Age or mental retardation prevented visual acuity measurements. Percentages indicated by numbers in parentheses.

Table 2 Complications in 108 patients with pupillary membranes removed via pars plana or plicata

\begin{tabular}{|c|c|c|c|c|}
\hline & Complications & $\begin{array}{l}\text { Membranes associated } \\
\text { with previous trauma }\end{array}$ & $\begin{array}{l}\text { Inflammatory } \\
\text { membranes }\end{array}$ & $\begin{array}{l}\text { Membranes following } \\
\text { congenital cataract procedures }\end{array}$ \\
\hline \multirow[t]{4}{*}{ SURGICAL } & Anterior segment bleeding & 4 & 2 & 0 \\
\hline & Posterior segment bleeding & 1 & 0 & 0 \\
\hline & Retinal detachment & 0 & 0 & 0 \\
\hline & Retinal tears & 0 & 0 & 0 \\
\hline \multirow{5}{*}{$\begin{array}{l}\text { EARLY } \\
\text { POSTOPERATIVE } \\
\text { ( } \leqslant 7 \text { days) }\end{array}$} & Striate keratopathy & 12 & 2 & 1 \\
\hline & Corneal oedema & 60 & 2 & 0 \\
\hline & Increased intraocular pressure & 12 & 1 & 0 \\
\hline & Hyphaema & 5 & 1 & 0 \\
\hline & Vitreous haemorrhage & 4 & 0 & 0 \\
\hline \multirow{5}{*}{$\begin{array}{l}\text { LATE } \\
\text { POSTOPERATIVE } \\
\text { (>7 days) }\end{array}$} & Transient corneal oedema & 2 & 2 & 0 \\
\hline & Residual corneal sedema & 0 & 0 & 0 \\
\hline & Hyphaema (repeat haemorrhage) & 2 & 0 & 0 \\
\hline & Retinal detachment & 5 & 0 & 1 \\
\hline & Glaucoma & 12 & 1 & 0 \\
\hline
\end{tabular}

anatomical success was obtained in all cases; 73 eyes $(67.5 \%)$ showed some degree of visual improvement (Table 1). The major operative complication was anterior segment bleeding, which was controlled by increasing the intraocular pressure (Table 2). This complication was noted more frequently with inflammatory membranes (Tables 1 and 2) in which the vessels were larger. Intracameral diathermy was necessary to control the bleeding in these cases.

Transient corneal oedema and striate keratopathy were the most commonly observed early postoperative complications (one to 7 days postoperatively). Transient corneal oedema was noted in 60 eyes and persisted for more than 2 weeks in only 2 eyes. Elevation of intraocular pressure was usually a transient phenomenon that occurred in 13 eyes in the early postoperative period. A total of 13 additional eyes developed long-term secondary glaucoma that was always associated with the previous blunt trauma and angle recession. In 4 of these eyes the vision worsened 6 to 24 months postoperatively, mainly because of poor compliance and loss of follow-up (Table 3).

Six patients developed rhegmatogenous retinal detachment (Table 4) as a late postoperative complication after $1 \frac{1 / 2}{2}$ to 23 months. Operative retinal tears or retinal dialyses were not produced. In none of the 108

Table 3 Reasons for worsening of vision after removal of pupillary membranes via pars plana or plicata

\begin{tabular}{|c|c|c|c|c|c|}
\hline \multirow{2}{*}{$\begin{array}{l}\text { Case } \\
\text { no. }\end{array}$} & \multirow{2}{*}{$\begin{array}{l}\text { Previous diagnosis } \\
\text { before surgery }\end{array}$} & \multirow{2}{*}{$\begin{array}{l}\text { Reason for worsening } \\
\text { of vision }\end{array}$} & \multicolumn{2}{|l|}{ Visual acuity } & \multirow{2}{*}{$\begin{array}{l}\text { No. of months of } \\
\text { postoperative worsening of } \\
\text { visual acuity }\end{array}$} \\
\hline & & & Postoperative & Final & \\
\hline 1 & $\begin{array}{l}\text { Blunt trauma with } 360^{\circ} \text { angle } \\
\text { recession }\end{array}$ & Intractable glaucoma & $6 / 60$ to $6 / 12$ & Light perception & 19 \\
\hline 2 & $\begin{array}{l}\text { Perforating corneal injury; } \\
\text { secondary glaucoma }\end{array}$ & Glaucoma; poor compliance & $6 / 120$ to $6 / 20$ & No light perception & 1 \\
\hline 3 & $\begin{array}{l}\text { Blunt trauma; angle recession } \\
\text { glaucoma }\end{array}$ & Glaucoma; poor compliance & Hand motions to $6 / 9$ & Light perception & 24 \\
\hline 4 & $\begin{array}{l}\text { Blunt trauma; angle recession. } \\
\text { seclusion of the pupil }\end{array}$ & Glaucoma; poor compliance & Hand motions to $6 / 120$ & No light perception & 6 \\
\hline
\end{tabular}


Table 4 Retinal detachment following pars plana and plicata membranectomy

\begin{tabular}{|c|c|c|c|c|}
\hline $\begin{array}{l}\text { Time of occurrence } \\
\text { after surgery (mo.) }\end{array}$ & Previous diagnosis & Retinal break & Condition of other eye & $\begin{array}{l}\text { Final vision after surgical } \\
\text { repair }\end{array}$ \\
\hline 12 & $\begin{array}{l}\text { Perforating trauma } 20 \mathrm{yr} \text { ago; } \\
\text { glaucoma and aphakia } 10 \mathrm{yr} \text { previously }\end{array}$ & $\begin{array}{l}\text { Retinal dialysis } \\
\text { (superonasal quadrant) }\end{array}$ & 3 peripheral retinal holes & $6 / 6$ \\
\hline 9 & $\begin{array}{l}\text { Congenital cataract with aspiration } \\
12 \mathrm{yr} \text { previously }\end{array}$ & $\begin{array}{l}\text { Inferior horseshoe tear at } \\
\text { equator }\end{array}$ & Lattice degeneration $360^{\circ}$ & $6 / 12$ \\
\hline 11 & $\begin{array}{l}\text { Blunt trauma and cataract extraction } \\
10 \mathrm{yr} \text { previously; iris neovascularisation; } \\
\text { status post panretinal photocoagulation }\end{array}$ & $\begin{array}{l}\text { Tractional hole, posterior } \\
\text { pole } 2^{\circ} \text { to proliferative } \\
\text { diabetic retinopathy }\end{array}$ & $\begin{array}{l}\text { Proliferative diabetic } \\
\text { retinopathy }\end{array}$ & $\begin{array}{l}\text { Enucleation (phthisis bulbi secondary } \\
\text { to complications of advanced } \\
\text { proliferative diabetic retinopathy) }\end{array}$ \\
\hline $1 \frac{1 / 2}{2}$ & $\begin{array}{l}\text { Corneoscleral laceration and } \\
\text { cataract removal } 14 \text { yr previously }\end{array}$ & Equatorial hole & Within normal limits & $6 / 60$ \\
\hline 18 & $\begin{array}{l}\text { Unplanned extracapsular cataract } \\
\text { extraction } 6 \text { yr previously; high myopia }\end{array}$ & Lattice with hole & $\begin{array}{l}\text { Lattice and hole without } \\
\text { detachment }\end{array}$ & $6 / 12$ \\
\hline 23 & $\begin{array}{l}\text { Corneal laceration; aphakic } \\
6 \text { yr previously }\end{array}$ & Superior equatorial hole & Within normal limits & $6 / 60$ \\
\hline
\end{tabular}

cases did vitreal traction bands arise from the sclerotomy site at the pars plicata or pars plana region. A rhegmatogenous retinal detachment occurred in one case 12 months postoperatively due to a retinal dialysis located in the superonasal quadrant in a patient with previous history of trauma. In the remaining 5 cases holes or tears occurred at different times and locations postoperatively (Table 4). All these cases were associated with a previous history of trauma, proliferative retinopathies, or extensive lattice degeneration.

\section{Discussion}

Short-term preliminary reports have shown that removal of pupillary membranes through a pars plana approach is feasible. ${ }^{14-17}$ Few operative complications were noted. The final visual outcome depended more on the status of the posterior pole of the eye and retina than on the anterior segment problems. ${ }^{1415}$ The results of the present study in a large number of patients confirm these previous observations and emphasise the few late complications and good final visual results with relatively long-term follow-up. They also show the posterior approach to be safe, particularly when the anterior segment has been subjected to previous surgical procedures and/or is compromised by previous trauma or inflammation or both.

The lack of complications originating from the sclerotomy site observed in the present series is probably related to a large scleral incision $(3.5$ to $4 \mathrm{~mm}$ long) and to its location $(2.5 \mathrm{~mm}$ from the limbus in children under age 3 years, and 3 to $4 \mathrm{~mm}$ from the limbus in older children and adults), which assures a safe distance from the ora serrata and avoids retinal dialysis due to improper insertion of the instruments.

Pupillary membranes can also be removed with a vitrectomy instrument inserted through a limbal incision. ${ }^{17}$ It is not possible at present to make a valid comparison of results with a limbal versus a pars plana or plicata approach because of the limited number of our cases in the former category. The pars plana and plicata routes avoid direct manipulation of the corneal endothelium, already compromised by previous surgery or trauma, and permit the removal of the pupillary membrane along with the anterior vitreous. Moreover, with the pars plana and plicata approaches the tip of the vitrophage can easily reach behind the iris in all axes to remove the lens remnants, a procedure that is rather difficult to perform through the limbal approach. An anterior limbal approach with a vitrectomy instrument may result more frequently in a collapsed anterior chamber, particularly when the membrane is thick and more suction is needed. Furthermore, it is virtually impossible with the limbal approach to place the vitrectomy instrument close to the surface of the retina, if it proves necessary to pick up fallen lens particles or excise preretinal debris or membranes.

Of the 6 patients who developed rhegmatogenous retinal detachment as a late postoperative complication, all had predisposing factors for retinal detachments, namely, trauma, ${ }^{2021}$ aphakia, ${ }^{21}$ myopia, ${ }^{22}$ lattice retinal degeneration, ${ }^{2-25}$ and proliferative diabetic retinopathy. ${ }^{26} 27$ Iatrogenic retinal tears were not produced in this series. Retinal dialysis occurred in only one case 12 months postoperatively (case 1, Table 4). The retinal dialysis in this case occurred in the superonasal quadrant away from and not connected to the sclerotomy site in the inferotemporal quadrant. In a recent analysis of 196 patients with retinal dialysis Zion and Burton ${ }^{28}$ found that unilateral nasal and superior dialyses were produced almost invariably by trauma, as in our case. The location and type of retinal breaks, the anatomical status of the retina, and the configuration of the retinal detachments did not implicate the vitrectomy procedure in a causative manner, but rather suggested that the previtrectomy status of the eye was more relevant to the subsequent development of the retinal detachment. 
Supported in part by core grant $1 \mathrm{P} 30 \mathrm{EY} 01792$ from the National Institutes of Health, Bethesda, Md, and grants from the Illinois Society for the Prevention of Blindness, Chicago, and Research to Prevent Blindness, Inc. New York City.

\section{References}

1 Arruga H. In: Hogan MJ, Chaparro LE, trans. Ocular Surgery. 2nd ed. New York: McGraw-Hill, 1956: 537.

2 Ballen PH. Micro discission in the anterior chamber. Ann Ophthalmol 1974; 6: 954-6.

3 Callahan A. Surgery of the Eye. Springfield: Thomas, 1956: 238.

4 Hiles DA. Wallar PH. Phacoemulsification versus aspiration in infantile cataract surgery. Ophthalmic Surg 1974; 5: 13-6.

5 Cotlier E. Surgery of secondary lens membranes. Surv Ophthalmol 1974; 18: 383-91.

6 Gass JDM. Surgical excision of persistent hyperplastic primary vitreous. Arch Ophthalmol 1970; 83: 163-8.

7 Kornzweig AL. Theodore FH. Secondary removal of residual lens capsule and cortex. Am J Ophthalmol 1961; 52: 463-8.

8 Shock JP. Gutman FA. Appleton B. Removal of dense secondary pupillary membranes following trauma: report of three cases. Ann Ophthalmol 1973; 5: 243-9.

9 Keates RH. Sherman RH. A technique for discission of secondary membranes. Ophthalmic Surg 1973; 4: 13-6.

10 Spaeth EB. The Principles of Ophthalmic Surgery. 3rd ed. Philadelphia: Lea and Febiger, 1941: 642.

11 Wiener N. Scheie HG. Surgery of the Eye. 3rd ed. New York: Grune and Stratton. 1972: 114.

12 Wheeler JM. Secondary cataract opening by single straight incisions: iridotomy by same method. Trans Am Acad Ophthalmol Otolaryngol 1924; 29: 179-90.

13 Yamashita T. Drews RC. Discission with the aid of a fixation needle (Soto technique). Am J Ophthalmol 1980; 49: 978-81.
14 Peyman GA, Swartz M. Management of dense secondary membranes with the vitrophage. Albrecht von Graefes Arch Klin Ophthalmol 1975; 195: 155-9.

15 Treister G, Machemer R. Pars plana approach for pupillary membranes. Arch Ophthalmol 1978; 96: 1014-6.

16 Peyman GA, Raichand M, Goldberg MF. Surgery of congenital and juvenile cataracts: a pars plicata approach with the vitrophage. Br J Ophthalmol 1978; 62: 780-3.

17 Taylor HR, Michels RG, Stark WJ. Vitrectomy methods in anterior segment surgery. Ophthalmic Surg 1979; 10: 25-58.

18 Peyman GA, Huamonte FU, Goldberg MF, Sanders DR, Nagpal KC, Raichand M. Four hundred consecutive pars plana vitrectomies with the vitrophage. Arch Ophthalmol 1978; 96: 45-50.

19 Richards RD, West CE, Meisels AA. Chorioretinitis sclopetaria. Am J Ophthalmol 1968; 66: 852-60.

20 Cox MS, Schepens CL, Freeman HM. Retinal detachment due to ocular contusion. Arch Ophthalmol 1966; 76: 678-85.

21 Weidenthal DT, Schepens CL. Peripheral fundus changes associated with ocular contusion. Am J Ophthalmol 1966; 62: 465-77.

22 Scheie HG, Morse PH, Aminlari A. Incidence of retinal detachment following cataract extraction. Arch Ophthalmol 1973; 89: 293-5.

23 Pemberton JM, Freeman HM, Schepens C. Familial retinal detachment and the Ehlers-Danlos syndrome. Arch Ophthalmol 1966; 76: 817-24.

24 Byer NE. Lattice degeneration of the retina. Surv Ophthalmol $1979 ; 23: 213-48$.

25 David MD. Natural history of retinal breaks without detachment. Arch Ophthalmol 1974; 92: 183-94.

26 Hilton GF, McLean EB, Norton EWD. Retinal Detachment. 3rd ed. Rochester: American Academy of Ophthalmology, 1979: 14. 15.

27 Liang JC, Goldberg MF. Treatment of diabetic retinopathy (review). Diabetes 1980; 29: 841-9.

28 Zion VM. Burton TC. Retinal dialysis. Arch Ophthalmol 1980; 98: $1971-4$. 